\title{
Atmospheric Content of Nigrospora Spores in Jamaican Banana Plantations
}

\author{
BY D. S. MEREDITH \\ Banana Board Research Department, Kingston, Jamaica, West Indies
}

(Received 21 April 1961)

\begin{abstract}
SUMMARY
The air in three Jamaican banana plantations was sampled from 20 July 1960 to 15 April 1961 with a Hirst spore trap. Spores of Nigrospora were regular components of the air-spora. They exhibited a regular and sharply defined diurnal periodicity, rapid liberation of spores starting at about $07.00 \mathrm{hr}$. and reaching a peak between 08.00 and $10.00 \mathrm{hr}$; very few spores were trapped during the night. This is consistent with the fact that spore discharge occurs only under conditions of decreasing vapour pressure. Rainfall and under-tree irrigation usually resulted in an appreciable increase in atmospheric content of Nigrospora spores. These high concentrations were maintained for 2-4 days before decreasing to characteristically low dry weather values. The highest daily mean concentration recorded was $1350 \mathrm{spores} / \mathrm{m} .^{3}$, an estimate of $c .14,000 / \mathrm{m}^{3}$ being obtained at $08.00 \mathrm{hr}$. on the same day.
\end{abstract}

\section{INTRODUCTION}

Since the introduction by Hirst (1952) of an automatic volumetric spore trap, much information about the air-spora in different parts of Britain has been collected (Hirst, 1953; Hirst, Storey, Ward \& Wilcox, 1955; Gregory \& Hirst, 1957 ; Gregory \& Sreeramulu, 1958; Gregory \& Stedman, 1958; Sreeramulu, 1959). In contrast, there is little information about the composition of the air-spora in or above tropical crops. Recent aerobiological studies in Jamaica (Meredith, 1961c,d) were chiefly concerned with the dispersal of Deightoniella torulosa, the cause of banana fruit-spot (Meredith, 1961 $a, b$ ). During this investigation it was observed that spores of Nigrospora were particularly common (Meredith, 1961e) and their dispersal is the subject of the present paper.

\section{Trapping methods}

METHODS

A Hirst spore trap with its orifice $3 \mathrm{~m}$. above ground was operated continuously from 20 July 1960 to 15 April 1961; sampling was at the rate of $14 \cdot 4 \mathrm{~m} .{ }^{3} / 24 \mathrm{hr}$. Three banana plantations were selected for study, all of them being situated on the lowland plains in St Catherine where extensive banana and sugar-cane plantations are established.

Plantation A, 20 July-1 September 1960, was irrigated at fortnightly intervals by admitting water into shallow trenches (surface irrigation).

Plantation B, 4 September 1960-29 January 1961. Under-tree irrigation was carried out at intervals determined by the distribution of rainfall. In this method, 
water is pumped along pipes and ejected through rotating nozzles set at intervals; pumping is usually continued for $48 \mathrm{hr}$. Since the water is sprayed several feet into the air, collapsed leaves hanging from the pseudostem are usually thoroughly wetted.

Plantation C, 15 March-15 April 1961. Conditions here were almost identical with those in $\mathbf{B}$.

The slides, changed daily at $09.00 \mathrm{hr}$. E.S.T., were prepared and scanned according to the methods of Hirst (1953). Since no corrections for variation in the efficiency of trapping were made, all spore numbers quoted are underestimates (Hirst, 1953).

Daily records of temperature, R.H. and rainfall were taken in the vicinity of the trap.

\section{Identity of Nigrospora spores}

Conidia of Nigrospora are unlikely to be confused with those of any other genus. They are black, shiny, globose when viewed from the end and elliptical from the side. Species recorded in Jamaica include:

Nigrospora sphaerica, which is, according to Simmonds (1933), the cause of 'squirter' disease of banana fruits in Australia. It is a widespread saprophyte on banana debris and has been recorded on many other monocotyledonous hosts (Mason, 1927).

$N$. oryzae, a very widespread saprophyte on the banana and many other monocotyledons (Mason, 1927; Wardlaw, 1935).

N. sacchari, occurring on both banana and sugar-cane leaves (Mason 1927; Simmonds, 1933).

Mason (1927) distinguished three species of Nigrospora on the basis of spore size: $N$. oryzae 13-15.5 $\times 10-13 \mu, N$. sphaerica 18-21 $\times 14-15 \mu$ and $N$. sacchari 18-24 $\mu$ in diameter. However, later he expressed doubt about this size criterion (Mason, 1933). In the present investigation it was found that spores measuring 13-18 $\mu$ predominated on the spore traces, suggesting that the dominant species trapped were $N$. oryzae and $N$. sphaerica, $N$. sacchari being infrequent. This is consistent with some observations on the relative abundance of these species in the plantations (Meredith, unpublished).

\section{RESULTS}

\section{Diurnal periodicity}

The diurnal periodicity curve (Fig. 1) obtained according to the method of Hirst (1953) includes data from all three plantations; each mean was from a total of 224 observations. Regular periodicity was evident, rapid liberation of spores starting after $06.00 \mathrm{hr}$. and reaching a peak between 08.00 and $10.00 \mathrm{hr}$. The concentration decreased rapidly during the afternoon and evening, very few spores being trapped during the night. On a few exceptional days the peak was not reached until about 12.00 or $14.00 \mathrm{hr}$., but on no occasion was the peak reached before $08.00 \mathrm{hr}$.

Liberation coincided with conditions of rising temperature and decreasing humidity, these usually occurring from $07.00 \mathrm{hr}$. onwards until about $14.00 \mathrm{hr}$. On damp mornings following rainfall during the previous night, humidity often showed no marked decrease until about $11.00 \mathrm{hr}$; ; on these occasions the peak concentration occurred after this time. Similarly, little or no liberation was evident between 08.00 and $12.00 \mathrm{hr}$. on the few occasions when it was raining at that time. 
Atmospheric content of Nigrospora spores

In Fig. 2 the daily mean spore concentration of Nigrospora is related to locality, rainfall and under-tree irrigation over the period 20 July-15 April 1961.

\section{Plantation A}

The 4 weeks prior to commencement of sampling were predominantly dry and the daily mean concentration averaged $c .100 / \mathrm{m}^{3}$. Traces of rain on 20 and 21 July were followed by an increase to $210 / \mathrm{m}^{3}$ on 22 July. A further 0.9 in. rain on this date

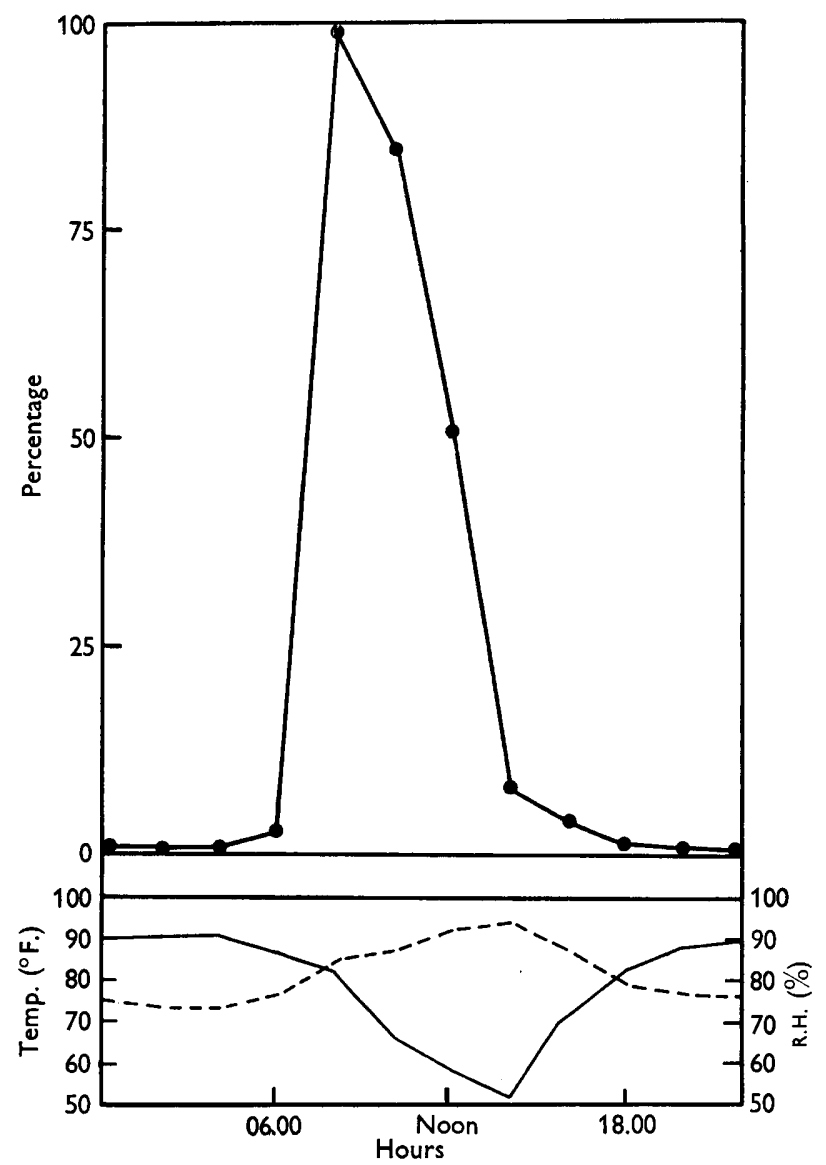

Fig. 1. Mean diurnal periodicity curve of Nigrospora expressed as a percentage of the peak arithmetic mean concentration. -..-, temperature; - , relative humidity.

and traces on the next 2 days resulted in a concentration of $450 / \mathrm{m}^{3}$ on $25 \mathrm{July}$. The next 7 days were dry and there was a progressive decrease in concentration to values of $c .100 / \mathrm{m}^{3}$. Rainfall on various dates in August resulted in similar temporary increases in daily mean concentration. The highest 2 -hourly concentration recorded in this plantation was $2400 / \mathrm{m}^{3}$ at $08.00 \mathrm{hr}$. on $25 \mathrm{July}$.

The fifteenth of August was exceptional in that a concentration of only $6 / \mathrm{m} .{ }^{3}$ was recorded. This was probably related to the fact that there was almost continuous 

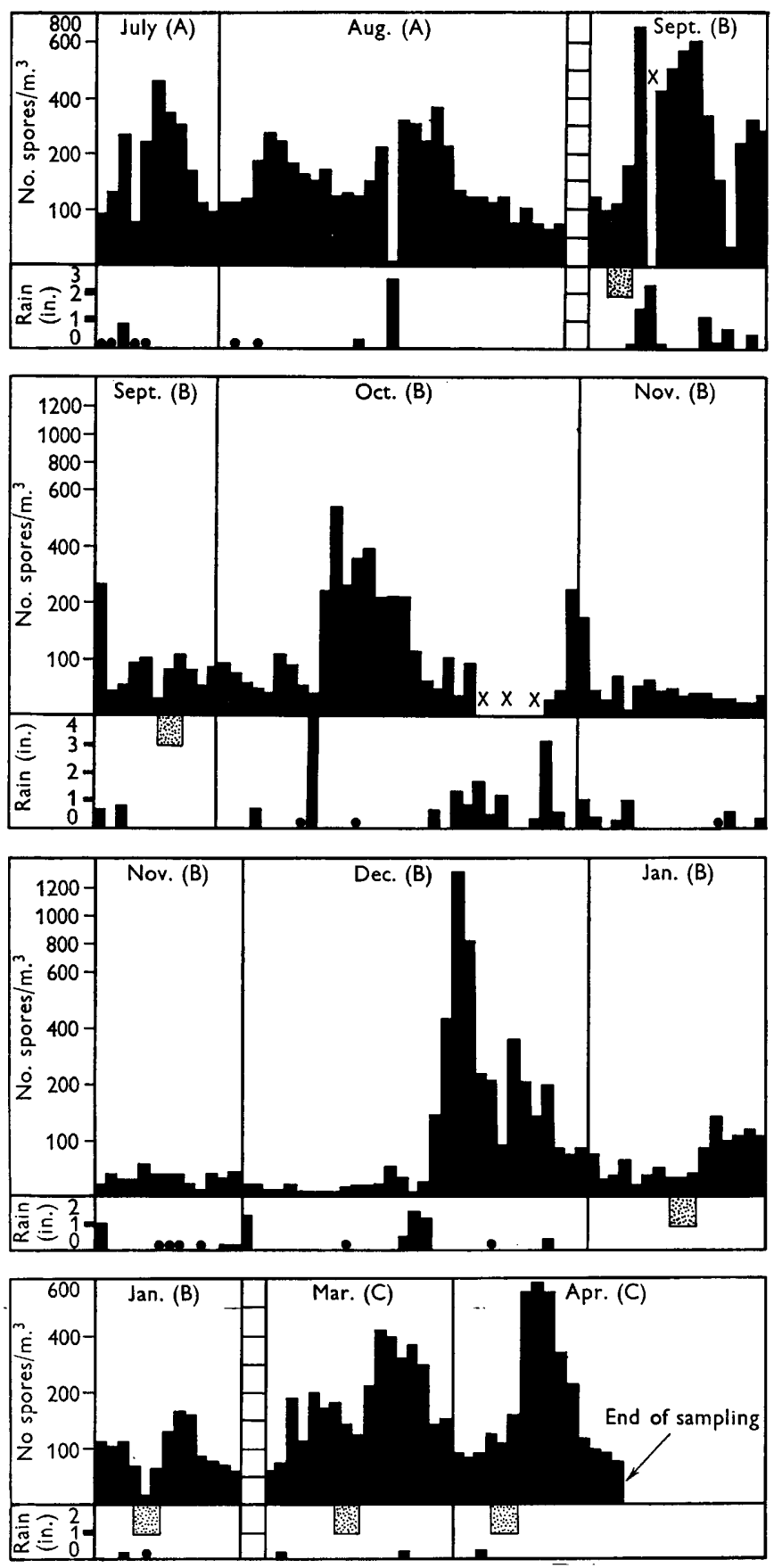

Fig. 2. Daily mean concentration of Nigrospora spores in three banana plantations (A, $B$ and $C$ ) related to rain and under-tree irrigation over the period 20 July 1960 to 15 April 1961. trace of rain; stippled areas indicate duration of under-tree irrigation periods; $x$, trap not operating. 
rainfall between 07.00 and $16.00 \mathrm{hr}$. on this date. Possibly rainfall occurring at the time of most rapid liberation removed many spores from the air almost immediately after their becoming air-borne. Alternatively, liberation might not have occurred due to unfavourable humidity conditions. A third possibility is that the source of spores was temporarily exhausted, but against this is the fact that relatively high concentrations occurred on both 14 and 16 August.

\section{Plantation $\boldsymbol{B}$}

September. Initially, the concentration averaged c. 100/m. ${ }^{3}$ Under-tree irrigation was carried out from 5 to 7 September and a total of $4 \cdot 13$ in. rain fell between 7 and 10 September. As a result of this, the concentration increased to $636 / \mathrm{m}^{3}$ on 8 September, an estimate of $2620 / \mathrm{m}^{3}$ being recorded at $08.00 \mathrm{hr}$. Daily means exceeding $300 / \mathrm{m}^{3}$ were maintained until 15 September when a value of only $30 / \mathrm{m} .{ }^{3}$ was obtained, possibly a result of rainfall occurring between 06.00 and $10.00 \mathrm{hr}$. The next 4 days yielded counts of more than $200 / \mathrm{m} .{ }^{3}$. Although there was more rain on 20 and 22 September and another under-tree irrigation period from 25 to 27 September, there was no appreciable increase in spore concentration.

October. The most notable feature was the greatly increased spore concentration following $4.12 \mathrm{in}$. on 9 October. The highest estimate recorded was $530 / \mathrm{m}^{3}$ on 11 October, and it was not until 18 October that values fell below $200 / \mathrm{m}^{3}$.

November. The concentration rarely exceeded $50 / \mathrm{m}^{3}$, there being no apparent response to rainfall.

December. The first half of the month was predominantly dry and up to 13 December the spore concentration never exceeded 50/m. ${ }^{3}$. Rain on 15, 16 and 17 December resulted in a relatively enormous increase in concentration during the subsequent 6-day period. On 20 December a concentration of $1352 / \mathrm{m} .{ }^{3}$ was recorded, this being the highest value recorded in any of the three plantations studied; a count of $c .14,000 / \mathrm{m} .^{3}$ was recorded at $08.00 \mathrm{hr}$. on this date. By 29 December the concentration had decreased to $84 / \mathrm{m}^{3}{ }^{3}$, there being no response to rain on 28 December.

January. This was a very dry month and concentrations exceeding $100 / \mathrm{m} .^{3}$ were recorded only after the two irrigation periods.

\section{Plantation C}

Increases in concentration were evident after rainfall and under-tree irrigation. The highest value recorded was $587 / \mathrm{m}^{3}$ on 8 April, the peak 2 -hourly estimate on this day being $5130 / \mathrm{m}^{3}$ at $08.00 \mathrm{hr}$.

\section{Spore projection in Nigrospora}

Webster (1952) has described violent spore discharge in Nigrospora sphaerica. Projection occurs under conditions of decreasing vapour pressure and appears to be due to the discharge of liquid through a fine orifice at the apex of a specialized conidiophore cell.

Colonies of Nigrospora occurring on decaying banana leaves were examined to discover whether violent spore discharge occurs on this substratum. Decaying leaf material was incubated for 2 days in a damp chamber to encourage spore formation. Thin strips of epidermal tissue were then rapidly transferred to the stage of a low- 
power binocular microscope. Within a few seconds, presumably as the tissues dried out, spores were shot away from the substratum; no discharge occurred when the strips of tissue were examined while inside damp Petri dishes. Light did not affect the discharge process. Thus Webster's (1952) findings were confirmed.

\section{DISCUSSION}

It is clear that Nigrospora is a common component of the air-spora in Jamaican banana plantations. The fungus exhibits regular diurnal periodicity similar to that in Nigrospora sphaerica in Nigeria (Cammack, 1955), Deightoniella torulosa in Jamaica (Meredith, 1961 c) and Phytophthora infestans and Polythrincium trifolii in England (Hirst, 1953). Hirst (1953) suggested that this type of periodicity might be due to the existence of a definite discharge mechanism operating each day under conditions of decreasing vapour pressure. Observations reported here, and earlier ones of Webster (1952) and Cammack (1955), support this suggestion in the case of Nigrospora.

Rain and under-tree irrigation commonly resulted in large increases in concentration of Nigrospora spores. This was probably a result of increased sporulation of the fungus after wetting of the spore-bearing substratum, namely banana debris. November's data were exceptional in that there was no response to rainfall. An explanation for this must await further investigation into the ecology of Nigrospora on banana debris.

Since Nigrospora is not responsible for diseases of economic importance in Jamaica, the results presented here have little apparent practical value to the local banana industry. However in Australia, where 'squirter' disease (Nigrospora sphaerica) often assumes serious proportions, similar aerobiological studies may contribute to a better understanding of the epidemiology of disease.

Grateful acknowledgement is made to the United Fruit Co., Jamaica, for granting access to their plantations, and to Miss B. I. McLean, Miss V. E. Green and Mr R. R. Chen for valuable technical assistance.

\section{REFERENCES}

CAmmack, R. H. (1955). Seasonal changes in three common constituents of the air spora in southern Nigeria. Nature, Lond. 176, 1270.

Gregory, P. H. \& Hirst, J. M. (1957). The summer air-spora at Rothamsted in 1952. J. gen. Microbiol. 17, 135.

Gregory, P. H. \& Sreeramulu, T. (1958). Air spora of an estuary. Trans. Brit. mycol. Soc. 41, 145.

Gregory, P. H. \& Stedman, O. J. (1958). Spore dispersal in Ophiobolus graminis and other fungi of cereal foot rots. Trans. Brit. mycol. Soc. 41, 449.

HIrST, J. M. (1952). An automatic volumetric spore trap. Ann. appl. Biol. 39, 257.

HIRST, J. M. (1953). Changes in atmospheric spore content: diurnal periodicity and the effects of weather. Trans. Brit. mycol. Soc. 36, 375.

Hirst, J. M., Storey, I. F., WARD, W. C. \& Wilcox, H. J. (1955). The origin of apple scab epidemics in the Wisbech area in 1953 and 1954. Plant Path. 4, 91.

Mason, E. W. (1927). On species of the genus Nigrospora recorded on Monocotyledons. Trans. Brit. mycol. Soc. 12, 152.

Mason, E. W. (1933). Annotated account of fungi received at the Imperial Mycological Institute. List II, Fasc. 2. I.M.I. Mycol. Paper, No. 2. 
MEREDITH, D. S. (1961 a). Fruit-spot ('speckle') of Jamaican bananas caused by Deightoniella torulosa (Syd.) Ellis. I. Symptoms of disease and studies on pathogenicity. Trans. Brit. mycol. Soc. 44, 95.

Meredith, D. S. (1961 $b$ ). Fruit-spot ('speckle') of Jamaican bananas caused by Deightoniella torulosa (Syd.) Ellis. II. Factors affecting spore germination and infection. Trans. Brit. mycol. Soc. 44, 265.

Meredith, D. S. (1961 c). Fruit-spot ('speckle') of Jamaican bananas caused by Deightoniella torulosa (Syd.) Ellis. III. Spore formation, liberation and dispersal. Trans. Brit. mycol. Soc. 44, 391.

MEREDrTH, D. S. (1961 d). Fruit-spot ('speckle') of Jamaican bananas caused by Deightoniella torulosa (Syd.) Ellis. IV. Further observations on spore dispersal. Ann. appl. Biol. 49, 488 .

Meredith, D. S. (1961 e). Nigrospora sp. and Botryodiplodia theobromae Pat. in the air of a Jamaican banana plantation. Nature, Lond. 189, 555.

Srmmonds, J. H. (1933). Squirter disease of bananas. Qd agric. J. 40, 98.

Sreeramulu, T. (1959). The diurnal and seasonal periodicity of spores of certain plant pathogens in the air. Trans. Brit. mycol. Soc. 42, 177.

WARdLAw, C. W. (1935). Diseases of the Banana, 1st ed. London: Macmillan.

WEBSTER, J. (1952). Spore projection in the Hyphomycete Nigrospora sphaerica. Nerw Phytol. 51, 229. 